\title{
Models of Rural Development and Approaches To Analysis Evaluation And Decision-Making
}

Modèles de développement rural et approches pour l'analyse, l'évaluation et la décision

lan Hodge and Peter Midmore

\section{(2) OpenEdition}

Journals

Electronic version

URL: http://journals.openedition.org/economierurale/406

DOI: 10.4000/economierurale.406

ISSN: 2105-2581

\section{Publisher}

Société Française d'Économie Rurale (SFER)

Printed version

Date of publication: 15 December 2008

Number of pages: 23-38

ISSN: 0013-0559

Electronic reference

Ian Hodge et Peter Midmore, « Models of Rural Development and Approaches To Analysis Evaluation And Decision-Making », Économie rurale [En ligne], 307 | septembre-octobre 2008, mis en ligne le 01 septembre 2010, consulté le 10 décembre 2020. URL : http://journals.openedition.org/ economierurale/406 ; DOI : https://doi.org/10.4000/economierurale.406 


\section{Models of Rural Development and Approaches To Analysis Evaluation And Decision-Making}

Ian HODGE and Peter MIDMORE • Department of Land Economy, University of Cambridge and School of Management and Business, Aberystwyth University

\section{Introduction}

T he recent increase in emphasis on evidence-based policy must be applauded from a number of perspectives. It is good from a social point of view because policy-making ought to be more precisely developed and targeted as a result of taking research findings into account; likewise, for academic and other researchers, more attention to their efforts to understand the mechanisms and impact of policy intervention provides an incentive to focus on immediate and relevant questions. However, in the specific case of rural development there are some fundamental barriers to analysis and evaluation of policy which need to be resolved. The most important of these stems from the fact that rural development, while it might reasonably in the past have been viewed in terms of sectoral policy, has shifted to a territorial policy, or arguably, further towards a "local" policy. Longstanding controversies exist regarding the nature, scope and definition of rural territory itself. Different designations provide arbitrarily different results, and those which are based on some kind of threshold such as that provided by the OECD (less than 150 persons per square kilometre) conceal what most commentators agree is a diverse range of socio-economic conditions (Hodge and Monk, 2004; Yarwood, 2005).

In England, the re-organisation of ministerial responsibility following on from the foot-and-mouth disease outbreak resulted in a Department of Environment, Food and Rural Affairs (Defra), at least part of which has a remit based on an uncertain geography: consequently, it sought an entirely new definition, based on an "underlying settlement classification" built up from the location of individual households, in an attempt to uncover the "needs of rural areas and communities" (Defra, 2004a) ${ }^{1}$. In England also (although not in the other constituent parts of the United Kingdom), levels of population density and urbanisation differ significantly in relation to the European norm, so that the classically assumed general equation between rurality and disadvantage is not valid. There are certainly some specific and intractable pockets of poverty and the socially mixed character of communities, but these are hard to identify (Cloke et al., 1994). In the United Kingdom, responsibility for rural policy and rural development has been complicated by the process of political devolution to constituent countries. The Westminster Government, represented by Defra (and previously one of its predecessors, the Ministry of Agriculture, Fisheries and Food), has overall responsibility on a European and international level, but in territorial terms covers only England. Elsewhere, the devolved administrations carry out the policy function and there is an increasing involvement at the regional level (Ward et al., 2003).

A further impediment to evaluation is caused by confusion over terminology. Since the Agenda 2000 reforms, most of the European Union's non-commodity European Agricultural Guarantee and Guidance Fund (EAGGF) spending has been consolidated into programmes delivered under the Rural

1. Cf. Page 5 . 
Development Regulation (RDR) ${ }^{2}$. Cursory examination reveals that the accompanying measures of MacSharry's Common Agricultural Policy (CAP) reform, consolidated into the "Second Pillar", are narrowly focused on farming and its environmental impact. Bryden (2000) $)^{3}$ has shown that less than $10 \%$ of planned expenditures under the 2000-06 RDR programmes were on "Article 33" measures focused on activities outside the agricultural sector, and consequently a negligible fraction of overall EAGGF payments. While there are some evident indirect linkages between agriculture and the non-farm rural economy, it is difficult to disentangle the various strands of EAGGF support, other Structural Funds activity, experimental LEADER funding and national programmes for rural action when attempting to link outcomes to activities. There is little evidence of radical change under the current Rural Development Regulation (Dwyer et al., 2007).

These are the challenges which the paper sets out to explore. The United Kingdom experienced a relatively early period of industrialisation and urbanisation in the $19^{\text {th }}$ century compared with other European countries and a consequent transformation of rural economies. More recently, in the $20^{\text {th }}$ century, there has been a period of significant counterurbanisation (Robert and Randolph, 1983; Champion, 1994) when populations have increased even in relatively remote rural areas. We set out a series of four models of rural development that seek to chart the changes in the predominant approaches to rural development over time. While they differ in their focus and spatial coverage, we argue that they represent dominant characterisations and policy approaches at particular points in time, and imply different types of analysis and scales of policy implementation. The models are influenced by changing economic and social

\footnotetext{
2. EC1257/1999.

3. $C f$. page 10 .
}

conditions in rural areas, the ways in which these conditions have been conceptualised into rural development theories, the political influence of different interest groups, and the policy approaches that have been implemented in practice. There is no clear linear causality amongst these factors; rather we see interactions amongst them in a simultaneous process of development. In practice, this has been an evolutionary process, more a continuum than a set of discrete changes. However, we argue that these four models do capture the characteristics of this more gradual change.

The paper ${ }^{4}$ relates these changing and developing contexts of rural development based on the experience within the United Kingdom to the implications for policy evaluation, using specific examples that show how the development of guidelines by both the United Kingdom Government (HM Treasury, 2003) and the European Commission (CEC, 1999) have contributed to making this a mechanical, path-dependent activity. It concludes by suggesting that although measurement of impacts on rural economies, environments and communities is a necessary component of overall evaluations, without more discursive and qualitative inquiry, it is not, alone, sufficient. This in turn has implications for the ways in which rural development decisions are made in practice. Given the relatively early experience of these trends within the United Kingdom following an early industrialisation and rural transformation (Grigg, 1982), there may be implications for the ways in which rural development is practised in other European countries as their rural areas pass through similar stages of development.

4. An earlier version of this paper was presented at the joint Société Française d'Économie Rurale and Agricultural Economics Society Conference on Rural Development, Paris, 29 March 2006. The authors are grateful for the helpful comments made by the referees. 


\section{The transformation of rural development}

There has been considerable recent discussion of the changes that are taking place in rural development both in terms of the nature of the changes underway within rural economies and in terms of the approaches adopted towards rural policy. The predominant characterisation is of a single change, commonly from an approach focussed fundamentally on the agricultural sector towards one focussed on rural territories and more diversified economic activity (Van der Ploeg et al., 2000; Léon, 2005; OECD, 2006). However, we argue that there has been a more steady process of economic and social change in rural areas over a longer period of time.

The figure 1 sets out the basic arguments, illustrating the four predominant models of rural development. The immediate post-war model centred on the agricultural sector. Increasing food production was a first priority and other objectives, such as enhancing rural employment and services, were seen as following directly from the production support given to the agricultural sector. But through time the approach has changed, shifting to multisectoral, territorial and local approaches. The multisectoral policy recognises the limits to agricultural production support and sees agriculture as one of several economic sectors through which the development objectives can be attained. The focus may still be on farming, but there is encouragement for agricultural diversification. The territorial approach recognises the wider interactions within the rural economy and the importance of social and environmental as well as economic issues. Finally, the differentiation between rural areas and the variation in individual circumstances within areas promotes a search for actions that recognise the specificity of solutions at most local levels. These changes have reflected both forces fundamentally associated with national economic change and other factors more governed by local circumstances. And they have major implications for the methodologies that are relevant for the analysis of rural problems and the evaluation of policies.

\section{A sectoral approach}

In the period following the Second World War there were overwhelming priorities that dictated the approaches taken to agricultural policy. These were driven by a need to ensure domestic food security and the central role of agriculture in rural economies as reflected, for instance, in the analysis and conclusions of the Scott Report (Committee on Land Utilization in Rural Areas, 1942). This placed support for the agricultural sector at the centre and promised a means of meeting a variety of objectives for food security, rural development, farm incomes and environmental protection simultaneously through a single agricul-

Figure 1. The evolution of rural development policies

General policy orientation
Agricultural Policy
of rural development


tural policy approach. In this model, agriculture represents the major sector in the rural economy and its success determines the performance of the local economy more generally. Agricultural decline promotes rural depopulation and a decline in rural service provision. Thus, a policy to stimulate agricultural production not only supports domestic food supply, agricultural employment and farm incomes, it also deters outmigration from rural areas and supports the rural economy and service provision more generally. However in the mid $20^{\text {th }}$ century, a variety of, by now familiar, factors undermined this approach and the general consensus about the appropriate policies. The high costs, inefficiency and environmental impacts of commodity price supports, especially in the context of surpluses of agricultural products undermined the approach taken to agricultural protection (Buckwell et al., 1982). The changing nature of technology applied in agriculture with increasing mechanisation and application of inputs imported from beyond the local economy reduced the local economic impact of agriculture. The combined decline in the significance of the agricultural sector and the widespread experience of counterurbanisation has meant that agriculture plays an increasingly less important role in the rural economy. In the United Kingdom for instance in 2006, agriculture was estimated to contribute some $0,5 \%$ of total value added at basic prices (Defra, 2007). But there is substantial regional variation; agriculture's shares in the English regions, varying in 2004 between $0,02 \%$ for London, and 0,6\% for the South East, to 1,3\% in the East Midlands and $1,7 \%$ in the South West.

\section{A multisectoral approach}

Thus, support directed exclusively through the agricultural sector faced increasing exchequer costs in terms of dealing with the agricultural surpluses that can result from increased production and with the declining relative importance of agriculture within rural areas which can have less and less local economic impact more generally. This suggests an alternative, multisectoral approach. The relatively small contribution of agriculture to many rural areas means inevitably that other economic sectors have come to play an increasing role in the rural economy. Recreation and tourism and more generally the service and industrial sectors have become dominant. With a continuing policy focus on supporting farm incomes, policy thus began to seek other approaches and in the later 1980s farm "diversification" became the "buzzword in policy circles" (Newby, 1988). Farmers were encouraged to look for alternative sources of income by adding value to agricultural products, by making use of farm assets, especially land and buildings for non-agricultural uses, by undertaking agricultural work on other farms and by becoming involved in non-agricultural economic activities off the farm. The emphasis on the diversification of the farm business subsequently broadened to a wider analysis of farm households and the potential for pluriactivity, drawing on multiple household income sources, as a strategy for long term farm household survival (Shucksmith, et al., 1989). This challenged the conventional view in the United Kingdom, in contrast to other European perspectives, that small farms represented only a temporary phase in the process of agricultural adjustment towards an agricultural sector based on full-time "efficient" farm businesses. Following this logic, it might be argued that the conventional view of agriculture as supporting the rural economy has come to be reversed to a situation where it is a successful local economy that offers the means of support for pluriactive farm households. While it was recognised that pluriactivity was not a new phenomenon, it gained an increased policy relevance. However, as noted by Gasson (1988) at the time, the goals of rural development might be pursued more effectively by encouraging 
employment completely unrelated to agriculture.

\section{A territorial approach}

However, even so, such an approach is only partially "multisectoral". A truly multisectoral approach to rural development policy would look more generally and equally at the actual and potential roles for other sectors in rural areas. While located in rural areas, these will often have no economic linkages at all with agriculture. The focus thus shifts towards a more general analysis of conditions within particular types of area, or a territorial approach. And in practice, this means a focus on rural areas. Rural areas can offer attractive locations for the establishment of new economic activity, often associated with the most advanced sectors of a modern economy, such as in information technology, and many areas have gained employment from the establishment of new firms and types of employment (Keeble and Tyler, 1995; North, 1998). This reflects the generally declining significance of transport costs in industrial production, the attractiveness of living in rural areas and the congestion costs of urban locations.

These socio-economic changes in rural areas have been associated with the breakdown of longstanding networks and linkages, such as associated with the supply of agricultural inputs and the marketing of agricultural products. In a context of relative agricultural decline the significance and penetration of agricultural norms is diminished within the wider community and this has not been replaced by any alternative single dominant perspective. In practice, we can recognise rural areas in a variety of different circumstances and facing quite different types of problem. But given the variety of circumstances found in rural areas, we may then suggest that most generalisations about the character of "rural" areas will be wrong (Hodge and Monk, op . cit.). Rural areas in the United Kingdom generally have performed relatively well in economic terms (Lowe and Ward, 2007) but particular areas continue to suffer from problems of low wages and underemployment. In areas with low activity rates and high unemployment, it may not matter very much what sort of economic stimulus is introduced. Any sort of new activity can have multiplier effects that work through to other sectors and may in turn promote new opportunities for farm diversification, thus supporting the farm population. In fact, it will often be easier to create employment opportunities through the development of non-land based activities, either by encouraging the movement of new economic activity into the area or through endogenous growth. The latter may be seen as more sustainable, although the former may be a more feasible alternative in areas where the economy is especially undeveloped.

In other areas, economic change is characterised by a rather different pattern of development, which we can term the "contemporary" model of rural change (Hodge, 1997); in contrast to the traditional model that is driven by changes within the agricultural sector. This recognises that a proportion of rural areas have a significant comparative advantage leading to economic success and population growth or counterurbanisation. This embraces a variety of different processes of varying importance across different localities. A major driving force behind it is the fact that rural areas offer attractive environments in which to live and work, while higher incomes and improved transport infrastructure reduce the constraints on locational choices. Thus those working in towns can travel longer distances to work, increasing the level of commuting. But the effect is more widespread than this; even relatively remote locations have experienced population growth. Earlier retirement has freed up older people to live in attractive locations away from a place of work. The increased congestion in urban areas and improved road and rail networks outside them have altered the relative acces- 
sibility of different types of locality; the less remote rural areas are generally more accessible than central urban locations that suffer from traffic congestion. Rural areas are also attractive to new forms of employment, often based on entrepreneurs choosing to establish new businesses in places where they want to live. Finally, there is anecdotal evidence of "downshifting", people deciding to opt out of more stressful employment to take up a less pressured lifestyle, often in a rural location. These have different impacts on different groups of the population. For instance, those living in rural areas tend to have higher income levels than those in urban areas, while those working there often have lower levels.

Thus rural areas often follow divergent paths, some in long term decline and others experiencing considerable prosperity. Some continue to be characterised by the "traditional' rural problems. Even if their populations are not significantly declining, they can often have low incomes and activity rates, although those on the lowest incomes are not necessarily engaged in the agricultural sector. Others with relatively high average incomes experience quite different sorts of problems. While the majority of the population is often generally well off and can get good access to services, there is a minority which experiences problems that are in many ways a consequence of the affluence of the majority, the fact that house prices are high or that, because the majority do not demand certain services such as public transport, they are not provided at all.

This divergence of experience across rural areas is seen in various ways. The higher numbers of people in some areas disguise the incidence of problems. Defra (2006) has recently highlighted the distribution of employees who are paid less than two-thirds of the English median wage. Concentration on the proportion of employees who are low paid highlights the more remote rural areas, but the absolute numbers of low paid employees are often higher in the less remote rural areas. Different conditions in rural areas can also be associated with different types of problems. We can, for example, identify two different sorts of problem associated with housing: poor housing conditions as represented by overcrowding or lack of facilities, or problems of access to housing as represented by a high level of housing costs relative to local incomes (Midgley et al., 2003). The different distributions of these indicators are shown in figure 2. Relatively high levels of both indicators of disadvantage are found in rural areas. But problems of housing affordability tend to be concentrated in the more affluent south-eastern part of the country around London, while problems of housing conditions tend to be concentrated in the more remote rural areas. Thus they might both be seen as "rural" problems, but relating to very different types of rural areas.

These issues suggest some limits to a general territorial approach, especially one that distinguishes simply between urban and rural areas. Changes in the circumstances in rural areas indicate a higher degree of complexity. There is no single sector that can be seen as a source of employment growth across rural areas in general. Rather, specific opportunities will depend on local characteristics, especially the natural environment, such as landscape, topography or an attractive coastline. It may also depend on the presence of employment clusters in nearby urban areas.

Other relationships also seem less straightforward. While it may have been assumed that the maintenance of population numbers will provide for the maintenance in the provision of local services, this no longer holds (Stockdale, 2004). Under the 'traditional' model of rural decline, the level of service provision falls with the reduced demand associated with a declining population and the emphasis in debate has generally been on the decline in services provided in rural areas. But in practice many other factors are associated with the level of 
Map 1 - Rank of access to housing, lowest 20\%

$\square$

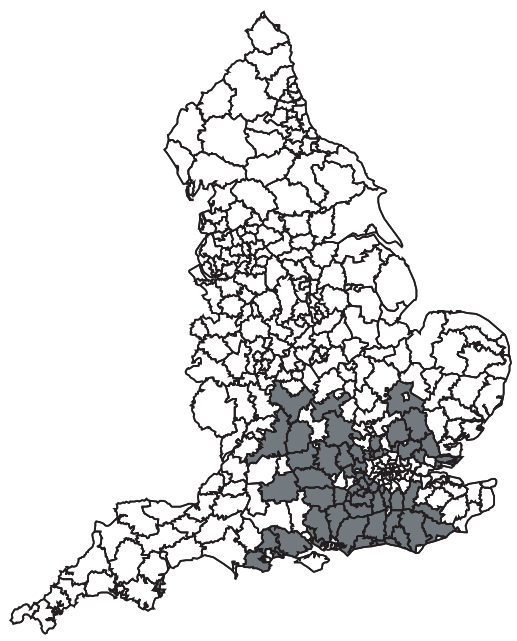

Map 2 - Rank of housing conditions, lowest $20 \%$

口

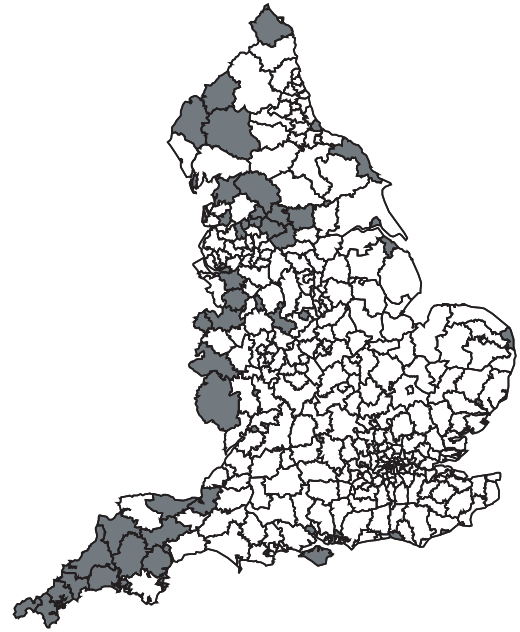

Source: Hodge and Monk (2004) service provision relating to both supply and demand. Economies of size and centralisation in the supply of services, increased personal mobility, privatisation of service providers and altered patterns of demand have also led to major changes in the way in which services are delivered.

The position is also complex when looked at from the perspective of particular individuals. An analysis of labour markets tends to assume that the presence of unemployment is a consequence of a lack of employment opportunities within the local labour market, with the obvious policy implication that the solution will lie in employment creation. However, there is a variety of factors that can prevent individual access to employment beyond a crude lack of vacant jobs (Hodge et al., 2002). These can include lack of transport, lack of childcare facilities or a mismatch between the types of jobs available and the skills of those without work.

\section{A local approach}

A response to these sorts of factors may be to adopt a "local" or even an "individual" approach. In principle, resources need to be directed towards particular problems at the individual household or business level. This is clearly an impossible task for a central or federal government and indicates the requirement for decentralisation of decision-making. But it may still not be feasible for a regional government and may demand an even more localised approach.

What is required is some mechanism for connecting the objectives and resources that are given for development policy at the national level to the problems and priorities that apply at the individual level. This is essentially a problem of information. The complexity of the problems and the diminution of traditional agricultural relationships have increased the attention given to the role of social capital and networks in the delivery of rural development (Lee et al., 2005). There needs to be a system whereby local circumstances can be assessed against national priorities and information disseminated to individual households and businesses on the opportunities and resources that can be made available in support of the objectives. This will not occur at a single step 
and the ease with which it occurs at all will depend on local institutions and the level of social capital. A sectoral approach required little institutional development at the subnational level. However, the move towards a territorial, and especially to a local approach, involves a much greater degree of choice and discretion in the ways in which public resources might be applied. This complexity makes far greater demands on information and local institutional developments are required in order to handle it.

Experience with rural development schemes to date suggests that they can be successful in the development of institutions and social capital, especially as embodied in the organisations that have been developed in order to facilitate the implementation of the schemes. Valuable initiatives have been made towards the development of local institutional structures through such schemes as Objective 5b and LEADER albeit in a sporadic and piecemeal way (Ward and McNicholas, 1998; Ray, 2000). But such initiatives are very small relative to the total volume of support for rural areas that continues to be put into rural areas through the Common Agricultural Policy. Local institutions have an important role in dealing with the increasing complexity of policy implementation by building social capital for dissemination of information, networking amongst participants and co-ordination of activities.

A variety of institutional arrangements and networks at the local level are involved, such as in public sector facilitation, by organisations such as local authorities or National Parks, development, housing and service provision associations, collective supply associations for environmental goods, local dedicated environmental funds, or conservation trusts. Some of these are purely in the public sector, such as local government facilitation. Others are essentially private, non-profit organisations, but generally substantially supported through government funding. Some develop hori- zontal associations, such as land management co-operatives, while others develop vertical associations, such as facilitation for the implementation of policy. More attention is needed on the optimal form and level of administrative intervention in the delivery of rural development policies. This sort of activity falls between the conventional roles of the public and private sectors, presenting a challenge to analysis that casts the two sectors in clearly separate roles. It introduces investment in and maintenance of social capital as legitimate elements of a rural development policy.

\section{Policy indicators and analysis}

These changes in the nature and pattern of rural development have profound implications for rural analysis and policy evaluation. In the positivist tradition (Weimer, 1998) policy evaluation is undertaken to test the efficiency and effectiveness of specific public actions designed to achieve social welfare benefits. For evaluation to work, therefore, policy objectives need to be unambiguously stated, and causal mechanisms need to be clearly understood. The latter is particularly important since other events or processes rather than the policy itself may affect the outcome. Increasingly, therefore, and especially in the study of rural development, there has been a search for validating measures, or indicators, which can discriminate whether policy action has been justified.

Such indicators should, according to the European Commission (CEC, 2001), cover efficiency (economic output in terms of quality and quantity, competitiveness and viability, and institutional efficiency) and equity (viability of rural communities and the maintenance of a balanced pattern of development, access to resources, services and opportunities, and labour conditions). Further, to appreciate the range of comprehension of different parts of the system and the stages at which policies impact, differ- 
ent kinds of indicators are required. Process indicators focus on policy implementation; output indicators provide quantitative measurements of effects identified as resulting from the policy; outcome indicators assess the extent to which policies achieve their stated objectives (Moxey et al., 1998).

Clearly, public resources for development assistance must be targeted on defined priorities. But two types of problems are often encountered in the targeting of rural development areas (Midgley et al., op. cit.) The first results from an 'urban' characterisation of local economic problems. While the approach has now changed, in the United Kingdom deprivation has in the past been assessed against indicators measuring children in flats, Commonwealth immigrants or overcrowded housing. None of these is representative of rural problems. No account was taken of the availability of local services, often a particular rural concern. Even an indicator of registered unemployment might be argued to be biased against rural priorities. In a large labour market, those who are unemployed can expect that regular job search will lead to the identification of a suitable employment opportunity. In contrast, in a small labour market people who are unemployed may well know that suitable vacancies are unlikely to occur and so decide to move to another area rather than remain unemployed within the local area. This suggests that recorded unemployment might be lower because of outmigration. Further, it may be that the costs of registering as unemployed are higher in a rural area because of the distance to be travelled to the employment office and the potential benefits lower as information might be more readily available by other, personal means. Thus we might expect that a rural area with a given level of economic disadvantage would exhibit a lower level of registered unemployment. This sort of argument might be generalised in that it is possible that the take up of social security benefits is on the whole lower in rural areas than it is in urban areas. This might reflect either the cost of registering to claim the benefit where it requires personal attendance in a local town, or else where social norms may give greater priority to independence and greater social stigma to claiming benefits from the state.

A second type of problem relates to the way in which data are generally collected and analysed in compiling indicators of local economic conditions (Fieldhouse and Tye, 1996). Thus, the smallest statistical unit within the Population Census is the enumeration district, the area covered by a single enumerator. These districts are then aggregated into larger statistical units on which the analysis is conducted. In urban areas, groups of people with similar socioeconomic characteristics tend to live in certain localities. These are often large enough to be identified as separate statistical units. However, within rural areas with smaller settlements, the unit will often include the whole settlement and so households with lower income will tend to be included together with those on higher incomes. Thus the mean figure for the rural unit may well fail to reveal the presence of a low income population.

The selection of indicators and the methods that are used to analyse and evaluate rural development policy are clearly associated with the underlying model of the rural development process and its objectives. Table 1 suggests the different indicators and methods that may be associated with the different rural development models. They also have different implications for the sort of information collected and the potential policy inferences.

The sectoral model concentrates on farm businesses and the means of raising farm incomes through agricultural production. Even where the emphasis has shifted from increasing production, there is clearly potential for development by investing to reduce costs and rationalise farm production structures. The methods of analysis draw partic- 
ularly on farm management but the approach clearly misses both the non-agricultural potentials for agricultural businesses and households as well as the conditions and opportunities in other sectors. The multisectoral approach recognises this wider economic environment and looks more generally at indicators of the state of the economy as a whole and the interrelationships between sectors. However, in practice the focus tended to remain on farm business and households. Development is still interpreted largely in terms of employment and so policy evaluation concentrates on the costs of creating new employment opportunities. This may suggest initiatives to attract new firms into the area or to stimulate employment creation from the development of endogenous resources. The territorial model recognises the wider set of social and environmental determinants of human welfare beyond employment and service provision. This suggests a cost-benefit approach that seeks to bring market and non-market values together into a single accounting framework. The approach remains quantitative and concentrates on quantifiable impacts and changes. The local model gives greater attention to the "softer" attributes of development. It seeks to recognise the variations in experiences amongst households and businesses within a particular local area and the significance of social and institutional capital in facilitating collective and community development. This indicates the introduction of qualitative research techniques, case studies or discourse analysis, and more deliberative approaches towards decision making. These different models and methods have direct implications for the sorts of information that may be available for policy decisions and hence for decision-making processes (table 1).

\section{Approaches in the United Kingdom}

Despite the contextual differences between the constituent parts of the United Kingdom, the articulation of policy and the framework of evaluation are relatively similar (perhaps because all four administrations share a common civil service,

Table 1. Indicators and methods in different development contexts

\begin{tabular}{l|l|l|l}
\hline Sectoral & \multicolumn{1}{|c|}{ Indicators } & \multicolumn{1}{c}{ Indicative methods } & \multicolumn{1}{c}{ Implications } \\
\hline Multisectoral & $\begin{array}{l}\text { Farm incomes } \\
\text { Agricultural population }\end{array}$ & $\begin{array}{l}\text { Farm models } \\
\text { Enterprise and } \\
\text { commodity studies }\end{array}$ & $\begin{array}{l}\text { Narrow focus misses } \\
\text { significant determinants } \\
\text { of rural welfare }\end{array}$ \\
\hline Territorial & $\begin{array}{l}\text { Farm household income } \\
\text { Employment } \\
\text { and unemployment } \\
\text { Local value added } \\
\text { Employment incomes }\end{array}$ & $\begin{array}{l}\text { Household surveys } \\
\text { Input-output analysis } \\
\text { Cost per job created }\end{array}$ & $\begin{array}{l}\text { May still be limited } \\
\text { to agriculture sector } \\
\text { Misses social and } \\
\text { environmental issues }\end{array}$ \\
& $\begin{array}{l}\text { Population change } \\
\text { Proportion of population } \\
\text { in disadvantage } \\
\text { Average incomes } \\
\text { Levels of service provision }\end{array}$ & Cost-benefit analysis & $\begin{array}{l}\text { Misses variations in } \\
\text { incomes and welfare } \\
\text { amongst population } \\
\text { and specific local } \\
\text { circumstances }\end{array}$ \\
\hline Local & $\begin{array}{l}\text { Social indicators } \\
\text { Numbers of people in } \\
\text { particular circumstances } \\
\text { Individual experiences }\end{array}$ & $\begin{array}{l}\text { Case studies } \\
\text { Qualitative analysis } \\
\text { Deliberative methods }\end{array}$ & $\begin{array}{l}\text { Capacity to consider full } \\
\text { range of experiences } \\
\text { but problems } \\
\text { with quantification } \\
\text { and aggregation } \\
\text { High transactions costs }\end{array}$ \\
\hline
\end{tabular}


and the cultural imprint of is strong). Thus, for example, in England prior to the outbreak of foot-and-mouth disease, there was a strategic review of the nature and role of rural economies (PIU, 1999), followed by a statement of rural policy published by the two responsible Westminster Ministries (DETR/MAFF, 2000). This established the scope of rural policy, which covers fair access to rural service provision, including housing and transport; business performance in both the farm and non-farm sectors; rural conservation and leisure uses of the countryside; and the vitality of communities and rural civil society. Attached to these four priorities are a series of 15 indicators. For economic development, for example, performance of policy initiatives has been measured from employment activity rates and unemployment rates in rural areas, the proportions of market towns that are thriving, stable or declining (based on service provision, business activity and employment), new business start ups and turnover of businesses in rural areas, total income from farming and off farm income, and levels of agricultural employment ${ }^{5}$. This suggests a dominance of the multisectoral model in policy-thinking.

The consequences of the foot-andmouth outbreak caused something of a paradigm shift (Scott et al., 2004), initially in terms of perception of the relative importance of constituent parts of rural economic activity, but perhaps more fundamentally a recognition that the administrative framework of policy delivery and evidence base was poorly suited to delivery of the policy objectives. In addition to a streamlining and reorganization of rural policy mechanisms, the new Rural Strategy (Defra, 2004b) provides a more detailed and comprehensive approach to policy evaluation, so that much of the introductory discussion of this paper is reflected in

5. Ibid., p. 96 its definition: "Evaluation is the process which objectively judges the actual outcomes, including any unintended side effects, of a policy or group of policies against the policy objectives, or intended outcomes, and the resources that are used in policy delivery".

The planned evaluation framework consists of several streams: improving statistical resources to establish a baseline for monitoring; using this to assess progress using the Rural White Paper indicators, and also the rural "Public Service Agreement" targets set for Defra by the Treasury ${ }^{6}$; rural-proofing the programme-based evaluation other Westminster ministries' policies; a study of local rural services; and either a longitudinal study of rural households or case studies of a number of rural communities, to examine crosscutting impacts of policies. When examining these policies themselves, however, there are some challenging complexities. The focus on economic and social regeneration is divided into two, sustaining the relative prosperity of the majority of rural territory, and more specific measures to address rural areas with economic and social disadvantage. Most of these consist of rural top-up funding for existing economic development policies (skills, business support, broadband technologies) delivered through other Ministries or their agencies, and some minor regulatory modification of the land use planning system. Improvement of the economic and environmental performance of farming and food production is argued to be directly relevant to economic regeneration, although the contribution it can actually make may be small ${ }^{7}$. The new paradigm may be seen as mixing the territorial and local models, with the more general territorial approach applying across rural areas, but recognising the

6. This is to "reduce the gap in productivity between the least well performing quartile of rural areas and the English median by 2008, demonstrating progress by 2006, and improve the accessibility of services for rural people" (HM Treasury, 2002, p. 111). 
potential for local variations in experiences and the role of case studies and some degree of decentralisation in decision-making. But it may be argued that the approach towards evaluation has not followed through the implications of the changes taking place, and there are inherent weaknesses in tracing the chain of causality from actions to impacts (Baslé, 2006).

\section{The status of analysis, evaluation and decision-making}

What may seem to be lacking from this approach is a revised conceptual framework that fully recognises the changed and differentiated circumstances of rural localities. In the context of a single dominant sector, support for this sector may well have trickled down to the population more generally, although even here there may be doubts as to the extent to which such support ever did get to those who were most in need. Contemporary rural change involves more complex interactions and interdependences in highly diverse contexts, so that as Saraceno (1999) ${ }^{8}$ argues, policies should "make different assumptions about factors influencing economic development and cannot be evaluated with the same tools that have been developed for homogeneous, single administration, top-down policies." Statistical generalisation based on replicated observation of a large number of cases is unhelpful since it has to assume things to be equal, whereas in most cases they are not.

7. According to Defra's own economic summary, regional agricultural gross valued added does not fully reflect the contribution of agriculture to rural economies... (and) ... presents a number of complexities as neither sectoral nor area based indicators currently provide a good basis for capturing the rural economy. Agricultural businesses account for $16 \%$ of all businesses in rural areas, but they only account for $7 \%$ of both employees and turnover. Employees in rural businesses are more likely to work in the manufacturing (17\%), tourism $(8 \%)$ and retail (15\%) industries.

8. Cf. p., 440.
Much more importance needs to attach to identifying the specifics and spatial distributions of problems and their causes; but also, it is necessary to reveal the causal processes that have the potential to resolve the problems. As has been indicated, this may well require novel developments in the civil society of rural areas, but we have little systematic information on the roles and impacts of networks and associations in improving social and economic conditions. And we know less about how they may be successfully established and sustained. Analysis crosses the boundaries between economics and sociology. Quantitative information is required on economic activities, but a necessary complement is required in qualitative analysis of the influence of networks, trusts or social norms.

In principle, a case study approach offers scope for development of an appropriate evaluative strategy for rural policy. Rigorous in depth study of carefully selected local areas, using a mixture of quantitative and qualitative data, can develop a sense of the interaction between increasingly diverse mixes of measures in contrasting rural contexts where different factors influence their expression and impacts, and contribute to understanding of how and why they operate in the way they do. This centre of interest of multiple case studies, described as a "quintain" by Stake (2006) is of a "contemporary phenomenon in a reallife context, especially when the boundaries between the phenomenon and context are not clearly evident" (Yin, 1994). Therefore, much of the preceding discussion can be related to Yin's strategic recommendations for case study design and implementation. These begin with selection and exploration of the objects of study, on the basis of general suppositions about the impact of policy which require testing. Multiple evidence sources should be scrutinized to test rival hypotheses, which might provide alternative explanations. Common protocols to investigate different expres-

9. $C f$. page 13 . 
sions of the phenomenon impart additional robustness. Analysis requires assessment of different patterns in the multiple data sources to refine and rule out competing hypotheses, both within individual case studies and between case studies carried out in different contexts (see, for example, Coffey and Atkinson, 1996) $)^{10}$.

The increased complexity and differentiation of rural development also has implications for the ways in which policy decisions may be made. Local diversity implies that decisions must vary at the local level, but an appropriate multi-level governance system for the administration of rural development undermines the traditional understanding of effective sovereign governments delivering policies and assessing their impacts. Differences exist in the operation of the networks of interests which have arisen to bridge the lack of coordination and consistency, overlapping with formal government structures and including specialist (and highly effective) interest groups, and informal frameworks embodied in conventions, each able to inhibit or facilitate the actions of others (Morrison, 2006). The incidence of these, their effectiveness in addressing disadvantage, their impacts, and efficiency in deploying limited resources and expertise are all poorly understood and require investigation. There is a risk that, rather than opening up opportunities to those who are excluded in present circumstances, they reinforce the influence of particular interests (see for instance Yarwood's, (2002) analysis of the operation of the rural exceptions policy and Shortall (2004)). Case study methods can contribute to understanding of what is analogous to diverse ecosystems of intersecting associations and organisations, businesses, infrastructures, and environmental systems (Edwards, 2004). Extending this metaphor, interaction, duplication, and synergy of rural civil society, and niche creation and

10. Especially Chapter 6. occupation, are additional conceptual tools for analysis and investigation.

In practice, though, significant barriers impede the development and application of such methods for improving understanding of the evolution, structure, and function of rural economies for refinement of policy design. Because case-studies require examination of a great many variables, in detail, in a small number of cases, they are relatively expensive, and skilled evaluators are scarce. There is a risk of becoming overwhelmed by detail in mixed method evaluations conducted at local level, due to their discursive nature. It is difficult to elaborate local level evaluation that fully reflects the complexity and diversity of rural areas, and at the same time convey the critical information back up to higher levels to permit balanced and informed decisions to be taken about resource allocation. Generalisation from case studies, especially from crosscase comparison where each individual study has been carried out in a consistent manner, is possible, but involves a different logic to conventional induction. In economic analysis, acceptance and consequent adoption of case study approaches is far from widespread (Bitsch, 2000) because they do not allow for the familiar statistical generalisations which come from large scale surveys. In contrast, theoretical generalisations deriving from identifying causal dependencies in one context contribute to better understanding of different mixes of influences in other rural areas. Our ability to make sense of different studies conducted in cases selected for varying purposes (of which an increasing number have now been completed: for example, Hart (2003); Lee et al. (2005); Midmore et al. (2004) is improving as a result of evolving prescriptions for rigorous meta-evaluation techniques (Cooksy and Caracelli, 2005).

Responding to these challenges will require a trade-off between qualitative evaluations to support decision-making at a more local level, closer to the level of pol- 
icy implementation, and the need to pass some information on performance back up to higher levels in order to permit higher level resource allocation and financial control. Perhaps this is the fundamental challenge to combine local level evaluation that fully reflects the complexity and diversity of rural areas, and yet to convey the critical information back up to higher levels to permit balanced and informed decisions to be taken about resource allocation across different regions and even countries.

\section{Thanks}

The authors are grateful for the helpful comments made by the referees.

\section{REFERENCES}

Baslé M. (2006). Strengths and weaknesses of European Union policy evaluation methods: ex-post evaluation of Objective 2, 1994-99. Regional Studies, Vo.40, $\mathrm{n}^{\circ} 2$, p. 225-235.

Bitsch V. (2000). Agricultural economics and qualitative research: incompatible paradigms? Forum Qualitative Sozialforschung (On-line Journal), Vo.1, $\mathrm{n}^{\circ}$ 1. Available at: http://www.qualitative-research.net/ fqs-texte/1-00/1-00bitsch-e.htm.

Bryden J. (2000). Is there a "New Rural Policy"? Paper presented at European Rural Policy at the Crossroads, Arkleton Centre for Rural Development Research, University of Aberdeen.

Buckwell A.-E., Harvey D.-R., Thomson K.-J. and Parton K.-A. (1982). The Costs of the Common Agricultural Policy. London, Croom Helm.

Commission of the European Communities (1999). MEANS collection: evaluating socio-economic programmes. Luxembourg, Office for Official Publications of the European Communities, 6 Volumes.

Commission of the European Communities (2001). A framework for indicators for the economic and social dimensions of sustainable agriculture and rural development. Agriculture Directorate General, Brussels, available at http://europa.eu.int/ comm/agriculture/publi/reports/ sustain/index en.pdf.

Champion A. (1994). Population change and migration in Britain since 1981: evi- dence for continuing deconcentration, Environment and Planning A, Vol.26, $\mathrm{n}^{\circ} 10$, p. 1501-1520.

Cloke P., Milbourne P., Thomas C. (1994). Lifestyles in rural England. Salisbury, Research Report, Rural Development Commission, Vol. 18.

Coffey A., Atkinson P. (1996). Making Sense of Qualitative Data. Thousand Oaks, CA: Sage.

Committee on Land Utilization in Rural Areas (1942). London, Report of the Committee on Land Utilization in Rural Areas. Cmd 6378, HMSO.

Cooksy L.-J., Caracelli V.-J. (2005). Quality, context, and use: issues in achieving the goals of metaevaluation. American Journal of Evaluation, Vol. 26, nº 1, p. 31-42.

Defra (2004a). Social and economic change and diversity in rural England. Defra Publications, London Birkbeck College, University of London, A report by the Rural Evidence Research Centre.

Defra (2004b). Rural Strategy 2004. London, Stationery Office.

Defra (2006). Rural Development Programme for England 2007-2013. London, Department for Environment, Food and Rural Affairs, Consultation.

Defra (2007). Agriculture in the United Kingdom. London, Department for Environment, Food and Rural Affairs.

DETR/MAFF (2000). Our Countryside: the future. A fair deal for rural England. London, Cm 4909, Stationery Office. Dwyer J., Ward N., Lowe P., Baldock D. 
(2007). European rural development under the Common Agricultural Policy's "Second Pillar": Institutional conservatism and innovation. Regional Studies, Vol.41, n7, p. 873-887.

Edwards M. (2004). Civil Society. Cambridge, Polity Press.

Fieldhouse E.-A., Tye R. (1996). Deprived people or deprived places? Exploring the ecological fallacy in studies of deprivation with the samples of Anonymised Records. Environment and Planning A, Vol.28, $\mathrm{n}^{\circ} 2$, p. 237-259.

Gasson R. (1988). Farm diversification and rural development. Journal of Agricultural Economics, Vol. 39, no 2, p. 175182.

Grigg D. (1982). The Dynamics of Agricultural Change. London, Hutchinson.

Hart K. (2003). Decentralized development in the European Union. Progress in Development Studies, Vol.3, $\mathrm{n}^{\circ} 1, \mathrm{p}$. 59-64.

HM Treasury (2002). Opportunity and security for all: investing in an enterprising, fairer Britain. London, Stationery Office, Public Spending Plans 2003-2006, Cm 5570.

HM Treasury (2003). The green book: appraisal and evaluation in central government. London, Stationery Office.

Hodge I. (1997). The integration of the rural economy. Built Environment, Vol.23, $n^{\circ} 3$, p. 192-200.

Hodge I., Monk S. (2004). The economic diversity of rural England: stylised fallacies and uncertain evidence. Journal of Rural Studies, Vol.20, no 3, p. 263-272.

Hodge I., Dunn J., Monk S., Fitzgerald M. (2002). Barriers to participation in residual rural labour markets. Work, Employment and Society, Vol.16, n $\mathrm{n}^{\circ}$, p. 455474.

Keeble D., Tyler, P. (1995). Enterprising behaviour and the Urban-Rural Shift. Urban Studies, Vol.32, no 6, p. 975-997.

Lee J., Árnason A., Nightingale A., Shucksmith D.-M. (2005). Networking: social capital and identities in European rural development. Sociologia Ruralis, Vol.45, $\mathrm{n}^{\circ}$ 4, p. 269-283.

Leon Y. (2005). Rural development in Europe: a research frontier for agricultural economists. European Review of Agricultural Economics, Vol.32, n ${ }^{\circ} 3$, p. 301-317.

Lowe P., Ward N. (2007). Sustainable rural economies: some lessons from the English experience. Sustainable Development, Vol.15, n 5, p. 307-317.

Midgley J., Hodge I., Monk S. (2000). Developing Indicators of Rural Disadvantage: Stage II. University of Cambridge, Department of Land Economy, Final report to the Countryside Agency.

Midgley J., Hodge I., Monk S. (2003). Patterns and concentrations of disadvantage in England: A rural-urban perspective. Urban Studies, Vol.40, n 8, p. 1427 1454.

Midmore P., Foster C., Schermer M. (2004). Organic Producer Initiatives and Rural Development: Four European Case Studies. University of Wales Aberystwyth, School of Management and Business, Organic Marketing and Rural Development Series, Vol. 3.

Morrison T.-H. (2006). Pursuing rural sustainability at the regional level: key lessons from the literature on institutions, integration, and the environment. Journal of Planning Literature, Vol.21, $\mathrm{n}^{\circ} 2$, $\mathrm{p}$. 143-152.

Moxey A., Whitby M., Lowe P. (1998). Agri-environmental indicators: issues and choices. Land Use Policy, Vol.15, n 4, p. 265-269.

Newby H. (1988). The Countryside in Question. London, Hutchinson.

North D. (1998). Rural industrialization. In B. Ilbery (Ed.), "The Geography of Rural Change”, Harlow, Longman, Chapter 8. OECD (2006). The New Rural Paradigm: Policies and Governance. Paris, Organisation for Economic Co-operation and Development. 
PIU (1999). Rural Economies. London, Stationery Office, Performance and Innovation Unit.

Ray C. (2000). The EU LEADER programme: Rural development laboratory. Sociologia Ruralis, Vol.40, n 2, p. 163 171.

Robert P., Randolph W.-G. (1983). Beyond decentralisation: the evolution of the population distribution in England and Wales 1961-1981. Geoforum, Vol.14, nº 1, p. $75-102$.

Saraceno E. (1999). The evaluation of local policy making in Europe: learning from the LEADER Community Initiative. Evaluation, Vol.5, n ${ }^{\circ}$ 4, p. 439-457.

Scott A., Christie M., Midmore P. (2004). Impact of the 2001 foot-and-mouth disease outbreak in Britain: implications for rural studies. Journal of Rural Studies, Vol.20, $\mathrm{n}^{\circ} 1$, p. 1-14.

Shortall S. (2004). Time to re-think rural development. EuroChoices, Vol.3, n ${ }^{\circ}$ 2, p. 34-39.

Shucksmith D.-M., Bryden J., Rosenthall P., Short C., Winter D.M. (1989). Pluriactivity, farm structures and rural change. Journal of Agricultural Economics, Vol.40, no 3, p. 345-360.

Stake R.-E. (2006). Multiple Case Study Analysis. New York, The Guilford Press. Stockdale A. (2004). Rural out-migration: community consequences and individual migrant experiences. Sociologia Ruralis, Vol.44, n 2, p. 167-194.

Van der Ploeg J., Renting H., Brunori G., Knickel K., Mannion J., Marsden T., de Roest K., Sevilla-Guzmán E., Ventura, F. (2000). Rural development: from practices and policies towards theories. Sociologia Ruralis, Vol.40, n 4, p. 391-408.

Ward N., McNicholas K. (1998). Objective $5 \mathrm{~b}$ of the structural funds and rural development in Britain. Regional Studies, Vol.32, n 4, p. 369-374.

Ward N., Lowe P., Bridges T. (2003). Rural and regional development: the role of the regional development agencies in England. Regional Studies, Vol.37, $\mathrm{n}^{\circ} 2$, p. 201-214.

Weimer D.-L. (1998). Policy analysis and evidence: a craft perspective. Policy Studies Journal, 26(1), p. 114-128.

Yarwood, R. (2002). Parish councils, partnership and governance: the development of "exceptions" housing in the Malvern Hills District, England. Journal of Rural Studies, Vol.18, n 3, p. 275-291.

Yarwood R. (2005). Beyond the rural idyll: images, countryside change and geography. Geography, Spring, Vol.90, p. 19-31.

Yin R.-K. (1994). Case Study Research. CA, Sage, Thousand Oaks. 